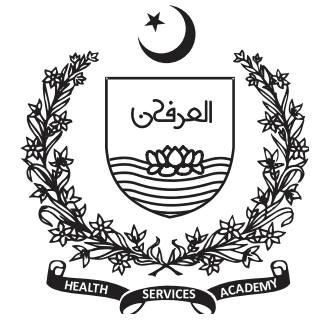

1Staff nurse TB hospital

Khairpur

${ }^{2}$ Associate Professor Health Services Academy

Islamabad

${ }^{3}$ Associate Professor

Nursing at SMBB Medical

University Larkana

${ }^{4}$ Consultant

Health-Strengthening

WHO Country office

Islamabad

${ }^{5}$ Assistant Professor

Nursing at ION DUHS

Ojha Campus Karachi

${ }^{6}$ Lecturer Nursing at SMBB

Medical University

Larkana

7Lieutenant Armed Force

Nurses PNS Shifa Karachi

Corresponding author:

Nazeer Ali Buriro,

Email: buriro13@gmail.com

\section{Nursing Now, Assessment of Contributing Factors among Nursing Youth in Pakistan at Sindh}

\author{
Faheem Ahmed Mallah¹, Shahzad Ali Khan², Nazeer Ali Buriro3 , Afifa Munawar4, \\ Badil Das ${ }^{5}$, Faiza Jokhio6, Amir Fatima7
}

\section{Abstract}

Background: Nursing is a Noble profession which is progressive and modernizing; As per need of the situation from a delivering baby and up to the dressing of injured it comes up with various specialties with high qualification of PhDs Nurses. The year 2019 was announced by the Honorable President of republic of Pakistan as Nurses year, keeping in view WHO has announced 2020 the year of Nursing and Midwifery. Authors have explored contributing factors for the selection of the nursing profession particularly and the motivation for future career in nursing.

Methods: A cross sectional descriptive study was conducted at rural district of Sindh which includes first year students of three nursing schools through structured questionnaire. Study duration was from October 2016 to February 2017. Sample of 91 participants collected through universal sampling technique (all available population was selected at study area).

Results: Respondent's family has a good image of nursing 62(68.1\%) participants were strongly agreed. Response of really want to see their self as a nurse $68(74.7 \%)$ participants were strongly agreed. Study showed many factors for taking admission in nursing $54(59.3 \%)$ participants responded their parents, Numerous personal factors like admiration nursing profession $58(63.7 \%) 68(74.7 \%)$ believed that they are caring for others. Many of them were enrolled due to the attraction of broad opportunities in nursing $45(49.5 \%)$.

Conclusion: According to our study findings most of the students chose nursing profession as an alternate but not their first choice, many personal, professional and financial factors attracted the students to get enrolled in nursing.

Keywords: Nursing Now; youth motivation; influential factors; nursing in Pakistan 


\section{Introduction}

$\mathrm{N}$

ursing is a Noble profession which is progressive and modernizing with time; it started back in Islamic era by caring of injured persons during and after war. As per need of the situation from a delivering baby and dressing of injured it comes up with various specialties including highly qualified PhDs Nurses. Along with the modernization of the world nursing developed professionally sound and practically assembled and research oriented. The year 2019 was announced by the Honorable President of republic of Pakistan as Nurses year in Pakistan, keeping in on priority WHO announced 2020 the year of Nursing and Midwifery around the globe. Resultantly in Pakistan nursing is a highly emerging field and the interest of youth is very particular for this profession. Nursing is defined as the protection, promotion, and optimization of health and abilities, prevention of illness and injury, facilitation of healing, alleviation of suffering through the diagnosis and treatment of human response, and advocacy in the care of individuals, families, groups, communities, and populations. By American Nursing Association(ANA)(1). Initially nurses from two countries United States and Canada were the founding members. This council is a federation of national nurses associations as the American Nurses Association and the Canadian Nurses Association. In 1981 national associations from different countries were affiliated with ICN through their membership(2). Pakistan Nursing Council was established in 1948. Pakistan got affiliation with ICN in year 1953. The PNC is an autonomous regulatory body constituted under the nursing council ACT (1952-1973). Core functions of PNC are to register and issuing of license for practice, setting curriculum for nursing education, policy formulation for nursing education (3). Pakistan is the $6^{\text {th }}$ most populous country in the world with population of about 180 million and overall literacy ratio is $59.9 \%$. Sindh is second most populous province in the Pakistan with more than 50 million populations and the literacy ratio in Sindh is $60 \%$ while male $64 \%$ and female $42 \%$.(4).

Nursing profession is advancing quickly in Pakistan; nurses are engaged in innovative and new methods of nursing care. There is a little awareness and co- operation evidence based from the other departments. There is a shortage of nursing professionals as compared with the international approved ratio of nurses in each country, This fact is still more worried if the population is increasing the prevalence of the diseases which ultimately is leading and an increase in the demand of the nursing care services(5).

Rational of the study

Motivation of the nurses have always been a point of concern for the efficiency of health care system but the youth has also a challenging task to choose career in a particular field. The performance of the nurses depends on highly motivated and passionate professionals. Particularly it is difficult to choose when people have misinformation about nursing profession, e.g social stigma, role of nurse as lower staff and some behavioral and ethical allegations. Beside this is well reputed and highly paid profession in the world. Hence it is important to determine the factors which motivate the students to choose nursing as a profession which will be helpful to motivate others to join nursing workforce. The study aimed to enhances knowledge of people for joining nursing profession. Authors have explored contributing factors for the selection of the nursing profession particularly and the motivation for future career in nursing.

\section{Methodology}

Study design was cross sectional descriptive and the study area were Schools of nursing civil hospital Khairpur, Sindhu School of male nursing and Sachal Sarmast institute of nursing Khairpur Mir's. Study population includes first year nursing students of three nursing schools of Khairpur for quantitative part of the study. Study duration was from October 2016 to February 2017. The total number of nursing students at study area (including all schools first years' students) was 97 among which the sample of 91 collected through Universal sampling technique (all available population was selected at study area). Selection criteria for the participants was first year nursing students present and willing to participate in the study because the new comers have ambitions and uncertainties about future, they may provide true picture of contribution factors. Inclusion criteria all the students enrolled in first year of nursing in all three nursing schools either public or private. Exclusion 
criteria of the study nursing students of other classes, instructors, and management were excluded from the study. A self-structured questionnaire developed from the themes of qualitative part which was used after pretesting in similar area in Sindh which was excluded from final study and validated with crowns alpha test result 0.82 , distributed among all willing participants of the first year of nursing in three nursing schools. Variables of interest were: Variety of career opportunities, alternate as fail to achieve other strategy, easy to find work, helping people, job security, caring contribution to society, relative in this field, following the parent's profession, Desirability for profession since growing age. Data was analyzed according to variables by Statistical Packages for Social Sciences (SPSS 21). Frequencies and percentages were computed and tables were formed. Results were presented in tabular form. Ethical consideration done as permission was taken from Institutional Review Board (IRB) of Health Services Academy (HSA). Verbal and written consent was taken from participant and privacy and confidentiality were maintained.

\section{Results}

Table.1 showing demographic characteristics of the participants as analyzed from data the number of participants according to their gender it was noted that $71(78 \%)$ were male while $20(22 \%)$ were female. The mean age of the study participants as analyzed the number of participants according to their age it was $64(70.3 \%)$ of the participants were in this age bracket majority of the people having in age between $16-20$ years category; the second majority $24(26.4 \%)$ of participants having age between 21-25 years category;(2.2\%) were having age in age of 26-30 years category and $1(1.1 \%)$ of participants fall in age of 31 or more years category. Participants according to their marital status it was noted that $84(92.3 \%)$ were single and $7(7.7 \%)$ were married which shows that majority of unmarried students are being enrolled in nursing. According to academic Qualification of the participants results showed that majority of respondent were having intermediate education $58(63.7 \%)$ and second most education was matriculation $23(25.3 \%)$ and $10(11 \%)$ were having university degree and were getting education of nursing.
Table 1: Demographic characteristics of the participants

\begin{tabular}{|c|c|c|}
\hline Biographical variables & $\begin{array}{l}\text { Frequency } \\
(\mathrm{N}=91)\end{array}$ & Percentage $\%$ \\
\hline \multirow[t]{2}{*}{ Gender } & Male & $71(78 \%)$ \\
\hline & Female & $20(22 \%)$ \\
\hline Age & $\begin{array}{l}16-20 \\
21-25 \\
26-30 \\
31 \text { or more }\end{array}$ & $\begin{array}{l}64(70.3 \%) \\
24(26.4 \%) \\
2(2.2 \%) \\
1(1.1 \%) \\
\end{array}$ \\
\hline Marital status & $\begin{array}{l}\text { Single } \\
\text { Married }\end{array}$ & $\begin{array}{l}84(92.3 \%) \\
7(7.7 \%)\end{array}$ \\
\hline Highest qualification & $\begin{array}{l}\text { Matriculation } \\
\text { Intermediate } \\
\text { University } \\
\text { degree }\end{array}$ & $\begin{array}{l}23(25.3 \%) \\
58(63.7 \%) \\
10(11.0 \%)\end{array}$ \\
\hline \multicolumn{3}{|l|}{ School name } \\
\hline $\begin{array}{l}\text { S.O.N Civil Hospital } \\
\text { Khairpur }\end{array}$ & 20 & 22.0 \\
\hline $\begin{array}{l}\text { Sindhu S.O.N Male } \\
\text { Khairpur }\end{array}$ & 25 & 27.5 \\
\hline $\begin{array}{l}\text { Sachal Sarmast S.O.N } \\
\text { Male Khairpur }\end{array}$ & 46 & 50.5 \\
\hline \multicolumn{3}{|l|}{ Type of school } \\
\hline Private & 71 & 78 \\
\hline Government & 20 & 22 \\
\hline \multicolumn{3}{|l|}{ Type of training } \\
\hline Stipendiary & 19 & 20.9 \\
\hline Self-finance & 72 & 79.1 \\
\hline \multicolumn{3}{|c|}{ How much you pay per month } \\
\hline 5000 or less & 4 & 5.6 \\
\hline $5000-10000$ & 43 & 60.5 \\
\hline $11000-15000$ & 18 & 25.3 \\
\hline 16000 and above & 6 & 8.4 \\
\hline \multicolumn{3}{|c|}{ Highest degree want to complete in nursing field } \\
\hline $\begin{array}{l}\text { Bachelor degree in } \\
\text { nursing }\end{array}$ & 16 & 17.6 \\
\hline $\begin{array}{lll}\text { Master degree in } \\
\text { nursing }\end{array}$ & 42 & 46.2 \\
\hline PhD degree in nursing & 26 & 28.6 \\
\hline Other & 7 & 7.7 \\
\hline
\end{tabular}

The school profiles of the participantsaccording to their institutions were $22 \%$ participants from S.O.N Civil Hospital Khairpur, 27.5\% were from Sindhu S.O.N Male Khairpur and 50.5\% were from Sachal Sarmast S.O.N Male Khairpur. Data was collected from two types of organizations/sectors in this study 
public and private institutes results showed that $22 \%$ of samples were collected from government sector Schools and 78\% from two private sector institutes. As per training it was observed that $19(20.9 \%)$ were stipendiary (paid by institute) while $72(79.1 \%)$ were self-finance type of training.

Question regarding per month total cost/fee either tuition or lodging and boarding at private schools' results showed that most of the students $43(47.3 \%)$ pay between 5000-10000 rupees per month, 18(19.8\%) participants pay between $11000-15000$ rupees, $6(6.6 \%)$ paid 16000 or more in a month and $4(4.4 \%)$ were paying less than 5000 per month while $20(22 \%)$ don't pay because they were studying in a government nursing school. The responses of question regarding ambition of highest qualification in nursing profession it was examine that $16(17.6 \%)$ responded for Bachelor degree in nursing, 42(46.2\%) interested to achieve Master degree in nursing, 26(28.6\%) responded for PhD degree in nursing and $7(7.7 \%)$ nominated other option that was elaborated as just any specialty in nursing after general nursing. Table 2 Analysis of the responses of question that who's influence, influenced you to take admission in nursing? It was analyzed that $48(52.7 \%)$ participants responded about their parents, 4(4.4) answered for career teachers, 17(18.7) answered
Table 2 Influence v/s decision to take admission in nursing

\begin{tabular}{|c|c|c|c|c|c|c|}
\hline $\begin{array}{l}\text { Influence to } \\
\text { take } \\
\text { admission in } \\
\text { nursing }\end{array}$ & $\begin{array}{c}\text { Freque } \\
\text { ncy }\end{array}$ & $\begin{array}{c}\text { Percent } \\
(\%)\end{array}$ & V/S & $\begin{array}{l}\text { Decision } \\
\text { to take } \\
\text { admissio } \\
n \text { in } \\
\text { nursing }\end{array}$ & $\begin{array}{c}\text { Freque } \\
\text { ncy }\end{array}$ & $\begin{array}{c}\text { Percent } \\
(\%)\end{array}$ \\
\hline Parents & 48 & 52.7 & & Parents & 54 & 59.3 \\
\hline $\begin{array}{l}\text { Career } \\
\text { teachers }\end{array}$ & 4 & 4.4 & & Yourself & 30 & 33.0 \\
\hline Friends & 17 & 18.7 & & & & \\
\hline \begin{tabular}{|l|} 
Close \\
relative \\
who is \\
nurse \\
\end{tabular} & 19 & 20.9 & & Brother & 5 & 5.5 \\
\hline Others & 3 & 3.3 & & Others & 2 & 2.2 \\
\hline Total & 91 & 100.0 & & Total & 91 & 100.0 \\
\hline
\end{tabular}

for friends, 19 (20.9) replied close relative who is nurse while 3(3.3\%) selected other option. When participants were asked who takes decision for you to take admission in nursing, it was examined that 54(59.34\%) participants responded about their parents, 30(33\%) answered that they took decision by themselves, 05(5.5\%) answered for brothers and 02(2.2\%) selected other options.

Table 3: Personal motivational factors for joining nursing

\begin{tabular}{|l|c|c|c|c|c|}
\hline $\begin{array}{c}\text { Personal factors for choosing } \\
\text { nursing }\end{array}$ & $\begin{array}{l}\text { Strongly } \\
\text { agree } \\
\text { Frequency } \\
\mathbf{( N = 9 1 )}\end{array}$ & $\begin{array}{l}\text { Agree } \\
\text { Frequenc } \\
\mathbf{y} \\
\mathbf{( N = 9 1 )}\end{array}$ & $\begin{array}{l}\text { Nor agree } \\
\text { neither disagree } \\
\text { Frequency } \\
\mathbf{( N = 9 1 )}\end{array}$ & $\begin{array}{l}\text { Disagree } \\
\text { Frequenc } \\
\mathbf{y} \\
\mathbf{( N = 9 1 )}\end{array}$ & $\begin{array}{l}\text { Strongly } \\
\text { disagree } \\
\text { Frequency } \\
\text { (N=91) }\end{array}$ \\
\hline $\begin{array}{l}\text { Do you admire, like nursing } \\
\text { profession }\end{array}$ & $58(63.7)$ & $29(31.8 \%)$ & $4(4.4 \%)$ & 0 & 0 \\
\hline $\begin{array}{l}\text { Do you believe that you are } \\
\text { caring for others }\end{array}$ & $68(74.7 \%)$ & $20(22 \%)$ & $3(3.3 \%)$ & 0 & 0 \\
\hline Are you helping others? & $67(73.6 \%)$ & $20(22 \%)$ & $3(3.3 \%)$ & $1(\% 1.1)$ & 0 \\
\hline $\begin{array}{l}\text { Does your Family have a good } \\
\text { image of nursing? }\end{array}$ & $62(68.1 \%)$ & $21(23.1 \%)$ & $6(6.6 \%)$ & $2(2.2 \%)$ & 0 \\
\hline $\begin{array}{l}\text { Do you really want to see } \\
\text { yourself as a nurse? }\end{array}$ & $68(74.7 \%)$ & $21(23.1 \%)$ & $1(1.1 \%)$ & $1(1.1 \%)$ & 0 \\
\hline $\begin{array}{l}\text { Do you think it can make a } \\
\text { difference? }\end{array}$ & $50(54.9 \%)$ & $28(30.8 \%)$ & $11(12.1 \%)$ & $1(1.1 \%)$ & $1(1.1 \%)$ \\
\hline $\begin{array}{l}\text { Do you want to have a Master } \\
\text { or PhD: degree in nursing }\end{array}$ & $44(59.3 \%)$ & $24(26.4 \%)$ & $10(11 \%)$ & $1(1.1 \%)$ & $2(2.2 \%)$ \\
\hline
\end{tabular}

Table.3 shows the analysis of the responses of questions that, what are the motivational factors to enroll you in the field of nursing? In the response of question do you admire, like nursing profession? 
58(63.7\%) participants were strongly agreed, 29(31.9\%) just agreed. Nurses are caring for others $68(74.7 \%)$ participants strongly agreed, 20(22\%) just agreed. In the response of statement to help others 67(73.6\%) participants strongly agreed. Respondent's family have a good image of nursing 62(68.1\%) participants strongly agreed. Response of statement do you really want to see yourself as a nurse $68(74.7 \%)$ participants strongly agreed, 21(23.1\%) just agreed. Respondents think that they can make a difference 50(54.9\%) participants were strongly agreed, 28 (30.8\%) just agreed. In the response of question do you think medical profession requires more commitment $55(60.4 \%)$ participants strongly agreed and 27(29.7\%) just agreed. Respondents were passionate about nursing profession $45(49.4 \%)$ were strongly agreed and $37(40.7 \%)$ were agreed. In the response of question are you willing to work irregular time, $46(50.5 \%)$ participants were strongly agreed and $30(33 \%)$ just agreed. In the response of question do

Table 4 Motivational factors and source of knowledge about field of nursing

\begin{tabular}{|l|c|c|}
\hline \multicolumn{3}{|c|}{ Knowledge about field of nursing } \\
\hline $\begin{array}{c}\text { Sources of } \\
\text { information }\end{array}$ & $\begin{array}{l}\text { Frequency } \\
\text { (N=91) }\end{array}$ & $\begin{array}{l}\text { Percentage } \\
\text { \% }\end{array}$ \\
\hline $\begin{array}{l}\text { Family member and } \\
\text { friends }\end{array}$ & 60 & 85 \\
\hline $\begin{array}{l}\text { School/college/ } \\
\text { university }\end{array}$ & 5 & 8.8 \\
\hline $\begin{array}{l}\text { By self when } \\
\text { admitted/ visiting to } \\
\text { hospital }\end{array}$ & 9 & 15.4 \\
\hline $\begin{array}{l}\text { By Gublic } \\
\text { agencies/ } \\
\text { libraries }\end{array}$ & 1 & 1.1 \\
\hline $\begin{array}{l}\text { Television } \\
\text { Govent }\end{array}$ & 2 & \\
\hline $\begin{array}{l}\text { Internet (Social media } \\
\text { and mass media) }\end{array}$ & 5 & 9.9 \\
\hline Newspaper & 9 & 11 \\
\hline
\end{tabular}

you want to work with sick? 53(58.2\%) participants strongly agreed, $22(24.2 \%)$ just agreed. In the response of statement regarding decision to join nursing college during school/college was decision made due to inspiration? 26(28.6\%) participants were strongly agreed, 30(33\%) were agreed. In the response of statement regarding decision to join nursing college during school/college do your family and friends forced into this profession? 12(13.2\%) participants strongly agreed, $15(16.5 \%)$ just agreed.

Table 4: Shows that $65.9 \%$ people answered that family members and friends gave them knowledge about nursing field, I contrast the school and college only gave information to $5.5 \%$ and by self when admitted /visited to hospital $9.9 \%$ of the students participants, by government agencies and public libraries only $2.2 \%$ get knowledge from the libraries, television introduced nursing profession to $1.1 \%$, internet and social media introduced nursing to only $5.5 \%$ of the participants while newspaper gave knowledge to $9.9 \%$ to the participants.

The results show that there is need to give knowledge about nursing profession in government agencies, newspaper and social media in positive way that may create $n$ image of nursing and all those students who don't have any knowledge regarding nursing profession and academies in public or private sector so they can get knowledge and can better serve the community and nation as well with clear image and future in nursing profession.

\section{Discussion}

Nursing profession is growing rapidly since last decade but quality of care and patient's satisfaction can be increased by our sincere services regardless of age, gender and religion. For achieving the optimal results for the better services of nursing it is necessary that person who is entering in this profession should be well motivated. This study was conducted to explore and assess the motivational factors which pulled the nursing students to get enrolled in this profession and many studies conducted round the globe to support my study both quantitatively and qualitatively. There are few government male nursing schools in Pakistan, most of them are in the Sindh province, government nursing schools in Sindh are only six out of twenty three government nursing school where they offer diploma in general nursing and private nursing schools in Sindh are twenty eight out of them twelve for males and three co-education male and female and thirteen for females which trained them in the field of nursing(3). 
Most of the results of my study are in accordance with an Australian study titled "The reasons that why students choose to take a nursing degree" in which they have quantified the reasons to take a nursing degree, in this study they have stated that students mostly choose nursing either due to their personal or career aspiration (6). Same results were also found in our study where most of the students are entering in nursing profession due to personal motivational factors like most of them admire, ,some wants to serve suffering humanity and other either impressed by family member, friends or relative in this field while career aspiration related students told that they choose nursing field as an alternate to MBBS, diverse field of work, broad career opportunities, safe and secure profession and stepping stone for any other filed(6). Results of our study are also compatible according to a study conducted in Cairo University with title "Work motivating factors as identified by nurses in children hospital at Elmonira and specialized Pediatric Hospital Cairo University that suggest that motivated nurses scored well as compared to those who were less motivated or neither motivated for joining nursing profession, most motivational factors were nature of work and pay and other financial benefits. Same results have been obtained by our study as main motivational factors for the students were diverse field of work and financial assistance during studies and easy to get job after training(7). In Australia study's findings reveals that nursing participants understood the values of nursing from theoretical and practical aspects, it also illustrates the entry in an organization and culture(8). A systemic review was carried out with the objective to assess the motivational factors that motivate youngster to choose nursing as their career, study suggest that this will help in recruitment policies for the future nurses specially for males(9). A study conducted in Lahore with the title "Reasons for selection of nursing profession in Pakistan" results of the study showed many reasons for selecting nursing as their profession most of them were enrolled due to their parents influence and some of them due to financial gain to support their family, few of them were interested to help and care suffering humanity and others were following the footsteps of others like family member or any relative in this field. (10).

Another study reports that $7 \%$ of nursing workforce are men, most of the participants were satisfied with their career choice. Respondents were worried about job recruitment strategies and career opportunity (11).
The process of entering nursing, as one of the pivotal healthcare discipline, certainly affects quality of care, and retention of nurses in the profession(12).Shortage of people entering professional nursing, dissatisfaction and high turnover of qualified nursing staff are issues that are of concern in many countries Almost same results have been found in our study as majority of the students responded that they joined nursing mainly due to personal, professional and financial gain, these themes have been merged as easy to get job, alternate to MBBS, social servicing, private and public jobs, emergency services and clinic set up in rural areas (13) Male students have a positive attitude toward men in the nursing but they do not prefer it as career. They said that, society reflects a limited desirability to the nursing profession(14)

\section{Conclusion}

According to our study findings it was clear that most of the students chose nursing profession as alternate but not their first choice because they think that there is less acceptability and poor image of nursing in the society. The majority has chosen nursing profession to support their families and for early employment opportunities. Research and evidence-based nursing policies should be made for creating a better image of nursing and to give every patient the service from the nurses according to their rights.

Limitation: This study is conducted at particular area therefor results cannot be generalized.

\section{Financial Support}

No financial support received which need to be declared.

\section{Conflict of Interest}

No conflict of interest

Acknowledgement

Sir Muhammad Mudasir for statistical guidance

\section{References}

1. Sochalski J, Melendez-Torres GJ. What Is a Nurse?"A Missioner of Health". Academic Medicine. 2013 Nov 1;88(11):1616.

2. http://www.icn.ch/who-we-are/icn-affiliates/

3. http://www.pnc.org.pk/PNC_Acts_-_Regulation.htm

4. Sehar-un-Nisa Hassan SS, Mahmood A. Achieving fertility control through woman's autonomy and access to maternal healthcare: Are we on track? In-depth analysis of PDHS-2012-13. Pakistan journal of medical sciences. 2015 Nov;31(6):1355. 
5. Brodie DA, Andrews GJ, Andrews JP, Thomas GB, Wong J, Rixon L. Perceptions of nursing: confirmation, change and the student experience. International journal of nursing studies. 2004;41(7):721-33.

6. Wilkes L, Cowin L, Johnson M. The reasons students choose to undertake a nursing degree. Collegian. 2015;22(3):259-65.

7. SAID RM, ABED FA, ABDO LM. Work Motivating Factors as Identifed by Nurses in Children Hospital at Elmonira and Specialized Pediatric Hospital Cairo University. The Medical Journal of Cairo University. 2013;81(2).

8. Lyneham J, Levett-Jones T. Insights into Registered Nurses' professional values through the eyes of graduating students. Nurse education in practice. 2016;17:86-90.

9. Yi M, Keogh B. What Motivates Men to Choose Nursing as a Profession? A Systematic Review of Qualitative Studies. Contemporary nurse. 2016(just-accepted):1-24.
10. Manzoor I, Daud S, Hashmi NR, Zafar M, Khan M, Zafar J, Babar S. REASONS FOR SELECTION OF NURSING PROFESSION IN PAKISTAN. Professional Medical Journal. 2010 Oct 1;17(4).

11. Twomey JC, Meadus R. Men Nurses in Atlantic Canada Career Choice, Barriers, and Satisfaction. The Journal of Men's Studies. 2016:1060826515624414.

12. Tayebi Z, Dehghan-Nayeri N, Negarandeh R, Shahbazi $S$. Motives for entering nursing in Iran: A qualitative study. Iranian journal of nursing and midwifery research. 2013;18(1):59.

13. Cho S-H, Jung SY, Jang S. Who enters nursing schools and why do they choose nursing? A comparison with female non-nursing students using longitudinal data. Nurse Education Today. 2010;30(2):180-6.

14. Abudari MO, Ibrahim AF, Aly AA. "Men in nursing" as viewed by male students in secondary schools. Clinical Nursing Studies. 2016;4(2):p41. 